\title{
A Study on Chinese College Students' English Pragmatic Competence
}

\author{
Zhang Yuanmin \\ College English Teaching and Research Section \\ Xi'an University of Technological Information \\ Xi'an, 710299, China \\ e-mail: 514729960@qq.com
}

\author{
Liu Gailin \\ Xi'an University of Technological Information \\ Xi'an, 710299, China \\ e-mail: luga888@163.com
}

\begin{abstract}
With the development of science and technology, cross-cultural communication becomes more and more important. Effect and efficiency of communications are dependent not only on linguistic competence, but also on pragmatic competence, namely, the non-native speaker's ability to use the language appropriately in different situations. However, under the great influence of traditional English teaching model and examination-oriented education, English pragmatic competence has been almost neglected in Chinese college English class. Therefore, Chinese college students' English pragmatic competence is to be explored. This research has been accomplished at one university in Xi'an. 100 college students were chosen as subjects of the research. Quantitative and qualitative research methods were applied to analyze Chinese students' English pragmatic competence. On the basis of the research results of the English pragmatic competence test and the questionnaires, some approaches are proposed to develop Chinese college students' English pragmatic competence.
\end{abstract}

Keywords-Chinese College Students; English Pragmatic Competence; English Pragmatic Failure; Teaching

\section{INTRODUCTION}

With the development of science and technology, transportation and information systems place us in instant and constant contact with people all over the world. The mobility of people and the contact between countries have greatly increased cross-cultural communication. With rapid development of China in economy and science, China has become one focus attracting much attention from all over the world and has more and more communication with all the other countries in the world. This requires a smooth, correct and effective communication with people from different cultures in order to reach the goal of cross-cultural communication. Therefore, more and more Chinese are required to have a good command of a foreign language, mainly English which is the most widely used language in the world. There's no exception to Chinese college students who need the competence for both appropriate and correct use for English language.

However, the Chinese College English teaching has been greatly affected by structuralism and examination-oriented education system. Both teachers and students attach too much time and energy to linguistic forms of English, but show little concern for appropriateness of English usage in actual situations and neglect social-cultural meaning, language functions, and the effect of context on the development of English linguistic and English pragmatic competence. In real situations, although Chinese college students have received several years of formal English education, they frequently remain deficient in the ability to actually use English. Many college students could not communicate with native English speakers smoothly even though they had gotten very high scores on English tests such as college English test band 4 (CET-4). That is because Chinese college students' inefficiency to correctly interpret the English pragmatic implication under a different cultural background. So this research aims at investigating Chinese college students' accuracy and especially appropriateness in applying English to real communication. Through analyzing Chinese college students' English pragmatic competence, this research puts forward some suggestions to help improve Chinese college students' English pragmatic competence.

\section{THEORETICAL FRAMEWORK}

With the study on pragmatics, more and more researchers demonstrate the importance of pragmatic competence. It is believed that pragmatic competence is the key to successful communication. However, there are vast numbers of Chinese college students whose proficiency is advanced and yet they continue to display unsuccessful pragmatic performance. The aim of Chinese college English teaching is to achieve freely communication with native English speakers, so Chinese college English teachers should pay attention to develop students' pragmatic competence.

In terms of pragmatic competence, Thomas(1983:110) gave such a comment: "Pragmatic competence can never simply be grafted on to grammatical competence and lead me to wonder whether there's not a point beyond which it is very difficult to acquire different pragmatic norms." Her words reveal the variation of pragmatic competence and reinforce the difficulty to understand pragmatic competence thoroughly. However, great efforts have been made to give it a definition. Thomas defines pragmatic competence as "the ability to use language effectively in order to achieve a specific purpose and to understand language in context" (Thomas 1983:94), and she and Levinson distinguish pragmatic competence between pragmalinguistic and sociopragmatic competence. Pragmalinguistic competence refers to the use of appropriate language to accomplish a speech act, whereas sociopragmatic competence refers to the appropriateness of a speech act in a particular context. In our country, He Ziran (1988 ) defined pragmatic competence as the ability to use a language in order to achieve a specific purpose and to understand language in context. Pragmatic competence is language user's an ability to recognize what context he or she in and what the speaker explicitly and 
implicitly means and to convey his or her intention correctly. All of these definitions show that pragmatic competence is concerned with the use of language in communication. So the development of linguistic competence alone does not guarantee pragmatic competence. Chinese college students have to be trained to develop their ability to understand or produce messages appropriately in the communicative contexts that can be social, cultural and situational. As we know that pragmatic competence is a part of communicative competence.

The concept of communicative competence was first made by Hymes as an alternative to the concept of the linguistic competence. Hymes (1972) put forward the concept of communicative competence, for he argued that besides linguistic competence, the native speaker has another rule system, that is, he knows intuitively what is socially appropriate or inappropriate and can adjust his language use to such factors as the topic, situation, human relation involved, etc. In other words, he defined it in terms of both the language and ability that individuals need to understand and use linguistic resources in ways that are structurally well formed, socially and contextually appropriate and culturally feasible in communicative contexts. According to Hymes, communicative competence is made up of four parameters: possibility, feasibility, appropriateness, performance. Possibility is whether or not something is formally possible. It is concerned with whether a language permits a sentence as grammatically possible. Feasibility refers to the ability to produce sentence that can be decoded by human brain. Appropriateness concerns the ability to use correct forms of language in particular situation. Performance refers to the fact that the utterance is completed. (Hymes, 1972)

In recent years, based on Hymes' notion of communicative competence, many linguists have done much on connotation of communicative competence, trying to clarify and refine the notion. Among them, Canale and Swain's findings are most influential in guiding foreign language teaching and learning, and they examine the relationship between theory and practice. They describe communicative competence, which contains grammatical competence, sociolinguistic competence, discourse competence and strategic competence. Canale and Swain's sociolinguistic competence, discourse competence and strategic competence could be regarded as a native speaker's pragmatic competence. It's generally accepted that sociolinguistic competence, discourse competence and strategic competence are grouped into the term "pragmatic performance" or "pragmatic ability". (Gao Yihong 2000) In our country, He Ziran (1984:36) defined communicative competence as "the ability to use and understand language appropriately in a variety of situations." He thinks that in learning how to speak, a child must not only have a good mastery of the vocabulary and grammar of a certain language, he must also absorb the social rules that govern how he should use his vocabulary and grammar in concrete situations.

Pragmatic competence is an essential component of communicative competence that the native speakers have in communication. Pragmatic competence and linguistic competence, two inseparable components of communicative competence, both are essential for a language user, since a successful language user's language should be not only grammatically correct but also pragmatically appropriate. In Chinese college English teaching, if we want to develop college students' communicative competence, it is necessary for us to pay more attention to the development of college students' pragmatic competence.

Pragmatic failure is a representation of poor pragmatic competence and if pragmatic competence is developed, the incidence of pragmatic failure will be corresponding reduced. Pragmatic failure was first put forward by Thomas. He defines that "pragmatic failure is an area of cross-cultural communication breakdown..."(Thomas, 1995). Thomas (1983) points out that interference in communication is generally referred to as pragmatic failure, which has nothing to do with the grammatical mistakes but comes from inappropriate ways of speaking or the unconventional expressions resulting from different perceptions of what is considered as appropriate linguistic behavior. In general, grammatical error belongs to language; pragmatic failure falls into language use. Actually, pragmatic failure occurs wherever the communicator could not use language appropriately or interpret language correctly. Thomas classified pragmatic failure into two groups: pragmalinguistic failure and sociopragmatic failure. Pragamalinguistic failure is caused by mistaken beliefs about pragmatic force of utterance and sociopragmatic failure is caused by different beliefs about right. (Thomas, 1983) He Ziran (1988:228) emphasizes that pragmatic failure cannot be separated absolutely. Because the intended meaning of what both sides says may be different due to the difference of linguistic contexts, therefore, some appropriate utterances may be pragmalinguistic failure from one point of view, but may also be sociopragmatic failure from another point of view.

\section{Methodology}

\section{A. Research Questions}

This research attempts to explore the current situation of Chinese college students' English pragmatic competence. This research adopts an unbalanced mixed design-both quantitative and qualitative designs are used but they differ in their roles in answering the research questions. In this research, the quantitative results play a dominant role while the qualitative findings are used to illustrate the quantitative results. To examine how well Chinese college students have developed their English pragmatic competence, questionnaires were designed to find answers to the following questions:

1) What's the current situation of Chinese college students' English pragmatic competence?

2) What is the relationship between the Chinese college students' English pragmatic competence and English linguistic competence? 


\section{B. Participants}

In this survey, 100 Chinese college students who are in the same grade at one university in Xi'an participated this study. They were divided into two groups. Group1 which consisted of 50 non-English major students from different departments were from grade three. They didn't pass Chinese College English Test Band Four (CET Band-4). Group2 which consisted of 50 non-English major students from different departments were also from grade three. They passed CET Band-4. CET Band-4 which is a Chinese national examination for non-English major college students pays more attention to the English linguistic competence test. So we can judge that on average Group 2's English linguistic competence is better than Group 1's. Basic information of all participants in this research is given in the following table 1:

TABLE I. INFORMATION ABOUT PARTICIPANTS

\begin{tabular}{|c|c|c|c|}
\hline Group & Number & Academic level & Gate \\
\hline Group1 & 50 & Not passed CET-4 & senior \\
\hline Group2 & 50 & Passed CET-4 & senior \\
\hline
\end{tabular}

\section{Procedures}

The research was done in the classrooms and finished by participants within 50 minutes. The participants were required to answer two parts questions according to their understanding and their own condition. Before the questionnaires were distributed to the participants, it was made clear to them that the purpose was only to test their English pragmatic competence. It has nothing to do with their marks. They had to do the questionnaires individually. If they had any English linguistic problems, they were allowed to consult teachers. Thus, participants could concentrate themselves on the English pragmatic aspects of the utterance in making their choices and give a valid representation of their English pragmatic competence.

\section{RESULTS AND DISCUSSION}

\section{A. Statistical Analysis of Chinese College Students' English pragmatic Competence}

The level of Chinese college students' English pragmatic competence is judged by their scores in the questionnaires. The higher the score is, the better the English pragmatic competence is, vice verse. According to Fig 1, the distribution curves of two groups can be roughly seen as in normal distribution. From the Table 2, it can be seen clearly that the means of each grade from Grade One to Grade Two are 50.70 and 54.22 points orderly against the full score 100 . The highest score is 79 and the lowest score is 18, and none of the Chinese college students who are surveyed get completely correct answers for all the choices in the English questionnaires. It reveals that the questions tested are somewhat difficult for Chinese college students. Chinese college students are not familiar with these kinds of questions. When facing the questions, Chinese college students felt confused with all the tested contents and could not choose the correct answers. All these results are worse than expected. The first research question has been answered that Chinese college students' English pragmatic competence is poor. So Chinese college English teaching and learning should attach great attention on cultivating college students' English pragmatic competence.

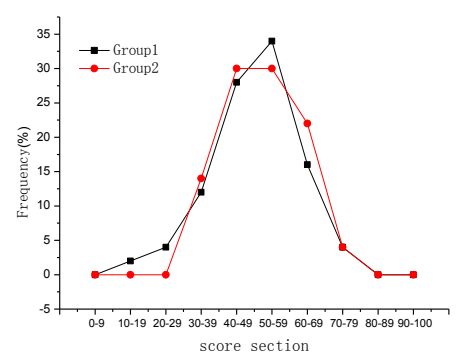

Figure 1. Students' Pragmatic Competence

TABLE II. DESCRIPTIVE STATISTICS OF PRAGMATIC COMPETENCE

\begin{tabular}{|c|c|c|c|}
\hline Participant & Minimum & Maximum & Mean \\
\hline Group1 & 18 & 76 & 50.70 \\
\hline Group2 & 38 & 79 & 54.22 \\
\hline
\end{tabular}

To answer the second research question, we analyzed the data of Group 1 and Group 2 through SPSS11.5 (the Statistical Package for the Social Sciences). As table 2

shows, we can see that the English pragmatic competence of Group and Group 2 is not statistically significant: their maximums are respectively 76 and 79, their minimums 18 and 38 , and their means 50.70 and 54.22 show roughly the same. T-test is often used to examine whether the differences between the means of the two samples are significant. In the present research, the T-test is applied to test the mean differences between Group 1 and Group 2. As is shown in the Table 3, the $\mathrm{P}$ value is 0.06 (marked differences are significant at $\mathrm{P}<0.01$ ), so there is no significant difference between Group 1 and Group 2. Although Chinese college students of Group2 have passed CET-4, their English pragmatic competence really lags behind their English linguistic competence. It also shows that Chinese college student who is proficient in English grammatical competence is not necessarily as proficient in English pragmatic competence. We can see that Chinese college students' English pragmatic competence does not necessarily grow together with their English linguistic competence if Chinese college English teachers do not purposely teach them the rules of using the English language. So, we can say affirmatively that there is no positive correlation between English linguistic competence and English pragmatic competence of Chinese college students.

TABLE III. PAIRED-SAMPLES TEST OF GROUP1 AND GROUP2

\begin{tabular}{|c|c|c|c|c|c|c|c|c|c|}
\hline & & \multicolumn{5}{|c|}{ Paired Differences } & \multirow{3}{*}{$t$} & \multirow{3}{*}{$\mathrm{df}$} & \multirow{3}{*}{$\begin{array}{l}\text { Sig. }(2- \\
\text { tailed) }\end{array}$} \\
\hline & & \multirow[t]{2}{*}{ Mean } & \multirow[t]{2}{*}{$\begin{array}{c}\text { Std. } \\
\text { Deviation }\end{array}$} & \multirow[t]{2}{*}{$\begin{array}{l}\text { Std. } \\
\text { Error } \\
\text { Mean }\end{array}$} & \multicolumn{2}{|c|}{$\begin{array}{l}95 \% \text { Confidence } \\
\text { Interval of the } \\
\text { Difference }\end{array}$} & & & \\
\hline & & & & & Lower & Upper & & & \\
\hline Pair1 & $\begin{array}{l}\text { Group1 } \\
- \\
\text { Group2 }\end{array}$ & 3.52 & 15.67 & 2.22 & -.93 & 7.97 & 1.59 & 49 & .119 \\
\hline
\end{tabular}


To make a further understanding of Chinese college students' English pragmatic competence, an analysis and comparison are made concerning their percentage of failure on English pragmalinguistic competence and English sociopragmatic competence. The results are presented in the following tables.

TABLE IV. DESCRIPTIVE PERCENTAGE OF FAILURE ABOUT PRAGMALINGUISTIC COMPETENCE AND SOCIOPRAGMATIC COMPETENCE

\begin{tabular}{|c|c|c|c|c|}
\hline $\begin{array}{c}\text { Type of } \\
\text { pragmatic } \\
\text { competence }\end{array}$ & $\begin{array}{c}\text { Mean } \\
(\boldsymbol{\%})\end{array}$ & $\begin{array}{c}\text { Minimum } \\
(\boldsymbol{\%})\end{array}$ & $\begin{array}{c}\text { Maximum } \\
(\boldsymbol{\%})\end{array}$ & $\begin{array}{c}\text { Std.deviation } \\
(\mathbf{\%})\end{array}$ \\
\hline $\begin{array}{c}\text { Pragmalinguistic } \\
\text { competence }\end{array}$ & 31.05 & 23.9 & 41.3 & 7.3 \\
\hline $\begin{array}{c}\text { Sociopragmatic } \\
\text { competence }\end{array}$ & 48.03 & 43.9 & 55.2 & 6.2 \\
\hline
\end{tabular}

The above table shows that Chinese college students' failure percentage is higher in English sociopragmatic competence than in English pragmalinguistic competence with average failure percentage 48.03 and 31.05 respectively. It shows some tendency of Chinese college students' advancement in English pragmalinguistic competence, compared with their English sociopragmatic competence. The result of the t-test of Chinese college students' English pragmalinguistic competence and English sociopragmatic competence proves significant difference between English pragmalinguistic competence and English sociopragmatic competence (see Table 5)

TABLE V. PAIRED-SAMPLES TEST OF THE COLLEGE STUDENTS' PRAGMALINGUISTIC COMPETENCE AND SOCIOPRAGMATIC COMPETENCE

\begin{tabular}{|c|c|c|c|c|c|c|c|c|c|}
\hline & & \multicolumn{5}{|c|}{ Paired Differences } & \multirow{3}{*}{$\mathrm{t}$} & \multirow{3}{*}{ df } & \multirow{3}{*}{$\begin{array}{l}\text { Sig. (2- } \\
\text { tailed) }\end{array}$} \\
\hline & & \multirow[t]{2}{*}{ Mean } & \multirow{2}{*}{$\begin{array}{l}\text { Std. } \\
\text { Devi } \\
\text { ation }\end{array}$} & \multirow{2}{*}{$\begin{array}{c}\text { Std. } \\
\text { Error } \\
\text { Mea } \\
\mathrm{n} \\
\end{array}$} & \multicolumn{2}{|c|}{$\begin{array}{l}95 \% \text { Confidence } \\
\text { Interval of the } \\
\text { Difference } \\
\end{array}$} & & & \\
\hline & & & & & Lower & Upper & & & \\
\hline $\begin{array}{l}\text { Pair } \\
1\end{array}$ & $\begin{array}{l}\text { pragmalinguistic- } \\
\text { sociopragmatic }\end{array}$ & -21.20 & 8.54 & 4.27 & -34.79 & -7.61 & -4.96 & 3 & . 016 \\
\hline
\end{tabular}

So English sociopragmatic competence is the main contributing factor of English pragmatic failure. According to Thomas, pragmalinguistic competence is languagespecific and pragmalinguistic failure can be solved by clear explanation of the linguistic form and sociopragmatic competence is largely culture-specific. Since the sociopragmatic failures results from cultural differences of views concerning what is appropriate social behavior in certain settings, college English teaching should pay a great attention to cultural background knowledge teaching and help students understand the cultural differences.

\section{B. An Investigation of the Fostering of Chinese College Students' English Pragmatic Competence}

English pragmatic competence is poor among Chinese college students, but what are the main reasons for this? How about the present Chinese college English language teaching? Based on the above analyses of the English pragmatic failures of Chinese college students, we give the same Chinese college students Questionnaire II to understand how well Chinese college students have learned their English pragmatics and cultural background knowledge.
TABLE VI. COLLEGE STUDENTS' ATTITUDES TOWARD PRAGMATICS AND CULTURAL BACKGROUND KNOWLEDGE LEARNING

\begin{tabular}{|c|c|c|c|}
\hline Very important & Important & $\begin{array}{c}\text { Not } \\
\text { important }\end{array}$ & No idea \\
\hline $10.6 \%$ & $23.5 \%$ & $50.8 \%$ & $15.1 \%$ \\
\hline
\end{tabular}

TABLE VII. PRAGMATICS AND CULTURAL BACKGROUND KNOWLEDGE TEACHING

\begin{tabular}{|c|c|c|c|c|}
\hline & $\begin{array}{c}\text { Pragmatics } \\
\text { introduction }\end{array}$ & $\begin{array}{c}\text { Culture } \\
\text { comparison }\end{array}$ & $\begin{array}{c}\text { Western } \\
\text { culture } \\
\text { introduction }\end{array}$ & $\begin{array}{c}\text { Lecture of } \\
\text { culture }\end{array}$ \\
\hline Usually & $5.6 \%$ & $12.6 \%$ & $24.1 \%$ & $17.2 \%$ \\
\hline Sometimes & $7.9 \%$ & $80.9 \%$ & $48.3 \%$ & $55.2 \%$ \\
\hline Seldom & $86.5 \%$ & $6.5 \%$ & $27.6 \%$ & $27.6 \%$ \\
\hline
\end{tabular}

We can see from Table 6 that: $50.8 \%$ of Chinese college students believe that English pragmatics and cultural knowledge learning is not important. Because of the pressure of exams, especially CET-4, Chinese college students' main concern is how to deal with the exam of Band Four. Most of Chinese college students pay more attention to English linguistic learning while ignoring English pragmatics and cultural learning.

Table 7 presents us that: a large number of Chinese college English teachers don't pay more attention to introducing some material about English pragmatics and English culture to the college students; sometimes the teachers impart the some knowledge about the western culture to the college students, but they seldom make comparison between Chinese culture and western culture. However, as Lado (1957) points out "The teacher has made a comparison of the foreign language with the native language and the students will know better what the real problems are". Underwood (1989) notes, "students will become more proficient in English if they increase their knowledge of the cultural context in which the language is used. Different cultures define social situations differently.". We can find that cultural background knowledge about the English is vital to English learning. So it is necessary for Chinese college English teachers to introduce English pragmatics and English cultural background knowledge to arouse Chinese college students' pragmatic competence.

\section{CONCLUSION}

With the rapid development of world multi-polarization, economic globalization and information technology, the successful and appropriate cross-cultural communication is very important. However, when communicating with English native speakers, Chinese college students failed to use English language appropriately. This phenomenon draws our attention. To examine how well Chinese college students have developed their English pragmatic competence, the research has been done in at one university in Xi'an. We have examined 100 Chinese college students' pragmatic competence from cross-cultural perspective. The research integrates quantitative and qualitative research and applies multiple methods to collect data. These findings show that enhancing the English cultural background knowledge and 
English pragmatics teaching and learning is of great importance in improving Chinese college students' English pragmatic competence.

\section{REFERENCES}

[1] J. L. Austin, "How to Do Things with Words," Oxford: OUP, 1962.

[2] S. Blum-Kulka, E. Olshtain, "Request and Apologies: A Crosscultural Study of Speech Act Realization Patterns (CCSARP)," Applied Linguistics, 1984.

[3] Z. A. Chen, J. R. Liu, "Contrastive English-Chinese pragmatics and TEFL," Beijing: Foreign Language Teaching and Research Press, 2002.

[4] Z. A. Chen, M. Huang, "Cross-cultural Pragmatic Failure and Culture Teaching in ELF," In Chen Zhi'an(eds.), Contrastive English-Chinese Pragmatics and TEFL. Beijing: Foreign Language Teaching and Research Press, 2002.

[5] Z. R. He, "Introduction of Pragmatics, Hunan Education Press,1988. 